\title{
Russian Engineering Universities in International Ratings
}

\author{
Leonid Sobolev \\ Moscow Aviation Institute (National Research University), Moscow, 125993, Russian Federation
}

Received September 23, 2020; Revised November 13, 2020; Accepted November 29, 2020

\section{Cite This Paper in the following Citation Styles}

(a): [1] Leonid Sobolev, "Russian Engineering Universities in International Ratings, "Universal Journal of Educational Research, Vol. 8, No. 12A, pp. 7487 - 7493, 2020. DOI: 10.13189/ujer.2020.082532.

(b): Leonid Sobolev (2020). Russian Engineering Universities in International Ratings. Universal Journal of Educational Research, 8(12A), 7487 - 7493. DOI: 10.13189/ujer.2020.082532.

Copyright $\odot 2020$ by authors, all rights reserved. Authors agree that this article remains permanently open access under the terms of the Creative Commons Attribution License 4.0 International License

\begin{abstract}
This article is devoted to the problem of improving the quality of engineering education in Russia in the context of global changes in the world economy associated with the fourth industrial revolution and the task of digitalizing the economy of the Russian government. Increasing competition in all civilian sectors requires highly qualified creative engineering staff to work in innovative companies. The lag of higher (including engineering) education from world standards is becoming more noticeable and is manifested in the low positions of Russian universities in international ratings. The transition to a market form of management and integration into the global economic system require, among other things, improving the quality of higher education in Russia, which should be confirmed by higher positions of Russian universities in international ratings. The purpose of this article is to help in choosing ways to reform Russian engineering education through a critical analysis of the experience of the world's leading technical universities. Taking into account international experience, the author proposes several ways to reform Russian engineering education. First, to diversify leading engineering universities by strengthening programs in basic sciences (physics, chemistry), life sciences (medicine, bioengineering) and humanities. Second, to strengthen the research sector of engineering universities by transferring to them a part of academic and industrial research institutes. Third, the reform of engineering universities should be coordinated with the diversification and partial conversion of state defense corporations.
\end{abstract}

Keywords University, Rating, Engineering Education, Reform, Vocational Training System, Research Work,
Connection with Production

\section{Introduction}

UNESCO engineering report published in 2010 found a general decline in the popularity of engineering specialties among young people and a decrease in the share of students of technical specialties compared to humanitarian ones. In addition, the report noted the importance of socio-economic disciplines in the training of engineers [1]. Employers are also urging changes in the engineering education system. The answer to this requirement was the development of a system of international educational standards in engineering: CDIO (Conceive, Design, Implement, Operate) Initiative. This international project aims to eliminate the contradictions between theory and practice in engineering education. It involves strengthening the practical orientation of training, as well as the development of problematic and design methods. In addition, the need to strengthen the practical training of engineers and the intensification of mutual exchanges of students are emphasized. Interest in this initiative was shown by several universities in Russia, including Tomsk Polytechnic University (TPU), Skolkovo Institute of Science and Technology (Skoltech), Moscow Aviation Institute (MAI), Moscow Institute of Physics and Technology (MIPT), etc. For international contacts, teachers and students need to have knowledge of English for free reading of specialized literature, communication with foreign colleagues, writing articles and reports for 
foreign publications. In addition, the economic training of future engineers should be strengthened for successful work in a market economy. First of all, this concerns the rejection of monopoly and the willingness to compete in the global competitive markets.

Interest in these ratings in Russia arose after the Decree of V.V. Putin's of May 7, 2012 "About the measures to implement state policy in the field of education and science", where there was the task of ensuring that by 2020 at least five Russian universities are in the top 100 universities in these ratings. The state program developed in accordance with this Decree was called "Project 5-100". More than 20 Russian universities of various specializations from were selected to participate in the competition, for which the government began to provide additional financial support.

It is becoming increasingly apparent that in the context of globalization of the world economy, the low competitiveness of domestic products is associated with the low positions of Russian technical universities in international ratings. However, we must understand that Russia is in a state of deep transformation of a command (planned) economy into a free market economy, which differs in their attitude to ownership of the means of production, pricing of goods and services, attitudes monopolization of any production and distribution, formation of a labor market and role of the Government in the economy and objectives of various economic entities.

Wrong strategy of economic transformation in the 1990s according to the author led to a deep economic downturn, high inflation and drop in the living standards of the population. In universities and research institutions, the real salaries of teachers and researchers fell, state funding for research decreased sharply, and many scientists emigrated abroad. The transition to a market economy requires reforming higher engineering education, in particular, improving the research base of technical universities, increasing the share of students' scientific and practical work, raising the prestige of teaching at universities, increasing the role of teaching English to communicate with foreign colleagues, etc. [2].

\section{Materials and Methods}

Currently, the quality (competitiveness) of training specialists in the higher education system is judged, in particular, by the position of a university in three authoritative international ratings: Quacquarelli Symonds (QS), Times Higher Education (THE) and Academic Ranking of World Universities (ARWU). Universities in three ratings are evaluated on the basis of several indicators with different weights: reputation (opinion of the academic community and employers about the university), quality of teaching (by the number of Nobel laureates and other well-known awards), publication activity and citation, number of foreign students and teachers and indicators of research work. Methodologically, these ratings are interconnected, and the difference is in which of the two areas of the university's activity (academic or scientific) is preferred [3, 4].

In international ratings, an assessment of a university is given not only by general indicators (World University rankings), but also by the subject principle, including engineering specialties. So, the subject QS rating 2019, which is analyzed in this article, covers 48 specialties, combined in five groups:

- $\quad$ Arts \& Humanities - A\&H;

- $\quad$ Engineering \& Technology - E\&T;

- $\quad$ Life Sciences \& Medicine - LS\&M;

- Natural Sciences - NS;

- $\quad$ Social Sciences - SS.

Engineering specialties usually include various areas (mechanics, aviation and space, computer technology and programming, electronics and electrical engineering, etc.) depending on the types of activities of the companies in the region. The companies, along with federal and local authorities, provide funding for the university and offer jobs to graduates. In leading Western universities, for which engineering is considered the main thing, there are usually training programs (faculties) for all groups of specialties, which allows students to change their specialty and conduct interdisciplinary research during their studies.

The following regions are represented in the top 100 universities in the QS subject E\&T ranking of 2019: North America (USA and Canada) - 27 universities; Europe - 29; Asia - 36; Australia - 6, Russia and CIS - 1; South America (Brazil) - 1. In Asia, most of the universities in the top 100 are in: China - 7, Japan - 7, South Korea - 6, Hong Kong - 5, Taiwan - 4, India - 3, Singapore - 2 and Malaysia - 2. The only Russian university that is in the top 100 of the QS rating is Moscow State University (57th position in E\&T, 90th position in the overall QS rating) [5]. Top 10 Russian universities included in the general and subject (E\&T) QS ratings are shown in the Table 1. 
Table 1. Top 10 Russian universities in the general and subject QS ratings of 2019

\begin{tabular}{|c|c|c|c|c|}
\hline № & University & $\begin{array}{l}\text { General QS } \\
\text { rating } 2019\end{array}$ & $\begin{array}{c}\text { Subject } E \& T \\
\text { rating } 2019 \\
\end{array}$ & $\begin{array}{c}\text { Subject } E \& T \\
\text { rating } 2018 \\
\end{array}$ \\
\hline 1 & Moscow State University * & 90 & 57 & 76 \\
\hline 2 & Saint Petersburg State University & 235 & 195 & 223 \\
\hline 3 & NSTU & 244 & 182 & 200 \\
\hline 4 & Bauman Moscow State Technical University * & 299 & 243 & 287 \\
\hline 5 & MIPT & 312 & 185 & 236 \\
\hline 6 & $\begin{array}{l}\text { National Research Nuclear University MEPhI } \\
\text { (Moscow Engineering Physics Institute) }\end{array}$ & 329 & 290 & 396 \\
\hline 7 & TPU & 373 & 277 & 286 \\
\hline 8 & Peter the Great St. Petersburg Polytechnic University & 404 & 224 & 248 \\
\hline 9 & National University of Science and Technology MISiS & 476 & 273 & 367 \\
\hline 10 & Information Technologies, Mechanics and Optics University & $511-520$ & 256 & $401-450$ \\
\hline
\end{tabular}

Source: QS World University Rankings by Subject 2019

* Universities not included in the Project 5-100

Table 2. Ranking of 5 best universities in the world in subject QS ratings 2019

\begin{tabular}{|c|c|c|c|c|c|c|}
\hline University & Country & E\&T & NS & LS\&M & SS & A\&H \\
\hline Massachusetts Institute of Technology (MIT) & USA & 1 & 1 & 6 & 5 & 16 \\
\hline Stanford University & USA & 2 & 2 & 4 & 3 & 5 \\
\hline Harvard University & USA & 12 & 3 & 1 & 1 & 2 \\
\hline University of Oxford & United Kingdom & 6 & 5 & 2 & 4 & 1 \\
\hline University of Cambridge & United Kingdom & 4 & 4 & 3 & 6 & 3 \\
\hline
\end{tabular}

There are two conclusions from the Table 1. Firstly, as a comparative analysis of the data of 2019 and 2018 shows, Russian technical universities have significant reserves of upward movement in subject (E\&T) and general QS ratings (4 universities were in the first two hundred). This movement, as it can be assumed, is associated with short-term factors, such as publication activity and fundraising from various funds. Secondly, if we compare the position of Russian universities in QS ranking of 2019 and 2010 (before the Decree), ten years ago Moscow State University held the 93rd position, Novosibirsk State Technical University (NSTU) 401-450, Higher School of Economics (project participant of 5-100) - 451-500, and the rest of the Russian engineering universities were not included in the top 500 of the world.

According to 3 international ratings, the universities of USA and United Kingdom are considered the best universities in the world. Table 2 shows the positions of 5 leading universities of the overall QS rating 2019 in subject QS ratings 2019.

In order to occupy a high place in the overall ranking, it is necessary to have high positions in all subject ratings. According to the author, this is one of the reasons for the low positions of the best Russian engineering universities in the overall QS rating. It must be understood that in Russia and abroad, first-year undergraduate students are sometimes disappointed in their chosen specialty and want to change it. In American and British universities, the choice of specialties or study programs is very large. For example, at MIT, famous for its developments in the field of computer technology, robotics and artificial intelligence, only $45 \%$ of students choose engineering specialties, the rest prefer to study economics, physics or history [6]. The only requirement is the number of "credits" that the student receives for the successful development of the discipline.

Only in the third year, the student must choose his specialization and the main area of professional interests for the final work. Moreover, graduation work can be performed at the junction of various professions. Students spend a lot of time doing research and projects related to the products of potential employers. Students who demonstrate success in research work can continue their studies as master students and in graduate school, and then pursue a career at the university. Some students think about creating their own business. A similar situation can be observed at Stanford and other leading engineering universities in the USA and United Kingdom. In Russia, changing the specialization within the framework of an engineering university is quite difficult.

All faculties (training programs) in the best engineering universities in the world rely on research laboratories (including NASA laboratories), where students, starting from the first courses, gain practical skills under the guidance of researchers and university professors. At the 
same time, universities have huge budgets comparable to the budget of the Russian Academy of Sciences, allowing them not only to fulfill orders of government agencies and large multinational corporations of civilian and military profiles, but also to maintain a staff of really strong teachers from around the world (including Russia).

As it can be seen from this short analysis, the best universities in the world are diversified and have strong academic and scientific positions in all subject groups of disciplines. In this regard, they continue the traditions of the XIX and even earlier centuries, adding new directions in accordance with scientific and technological progress. A similar structure was partially preserved by pre-revolutionary Russian universities (Moscow State University, St. Petersburg State University, Kazan and Tomsk Universities). However, after exhausting short-term factors (publication activity, attracting additional funds and foreign students), getting into the cherished "hundred" requires the use of long-term factors, such as increasing the effectiveness and importance of scientific activity and the status of the faculty and researchers of the university. This is clearly illustrated by the example of Moscow State University, which for the last 10 years has actually been "stuck in place" at the end of the top 100 QS ratings due to the lack of significant scientific results.

As for many Russian universities, students do not always find in them interesting fields of activity and leave to work in foreign universities. For example, at MIPT, many graduates found something they like abroad, points from the Nobel Prize in Physics A. Geim and K. Novoselov for the discovery of graphene went not to MIPT, but to MIT, where these scientists conducted their research and got an outstanding result. As for MIPT, it should be noted that it is trying to maintain relations with graduates and is establishing international contacts through them.

Most Russian universities (not only technical ones) created in the 1930s (Moscow Power Engineering Institute, MAI, State Technical University - MADI, etc.) are of a sectoral nature, trained and continue to train specialists for the respective industries, although the concept of "industry" is everywhere replaced by the concept of "type of economic activity". According to the author, technical universities with the status of "national research universities" (especially in megacities) should gradually move away from a narrow industry focus, as the best universities in the world do (Table 2). This will strengthen the civic segment of these universities, provide a wider selection of specialties for the youth of these megacities and visitors (including foreigners), conduct interdisciplinary research and reduce the burden on public transport.

\section{Materials and Methods}

In recent years, the triple helix theory has gained popularity in the international university community, which traces the relationship between universities as sources of innovation, high-tech companies sponsoring university science and the state providing university science with orders and grants [7, 8].

The connection between the theory of the triple helix and international ratings is obvious, since the scientific achievements of universities (innovations introduced in the industry) make a significant (if not the main) contribution to the university's position in the subject and general ratings. Traditionally, business and state were drivers of industrial policy, however, at the present time, when innovations began to be implemented faster in university laboratories, university science representatives creating startups came to the fore. Commercialization of innovations now allows inventors to participate not only in the research process, but also to create innovative companies (HP, Google, Apple, etc.). This phenomenon is the main argument for a deeper involvement of universities in the innovation process.

The competitive advantage of universities is the constant influx of creative youth: students who inevitably generate new ideas. The contrast looks convincing in comparison with the conservatism of state research institutes, which are deprived of the continuous influx of innovations provided by universities at the expense of students, graduate students, professors and researchers. According to the author, the anachronism is the division of science in Russia into 3 branches: university, academic and industry, since the last two are rooted in universities. The long-term strategy for the development of higher education in Russia should be differentiation of industry universities and transfer to universities of the "center of gravity" of basic and applied research with appropriate funding. The merger of university and academic branches of science should benefit them: to increase scientific potential for universities, to rejuvenate the staff of Russian Academy of Sciences. It is advisable to keep separately only military research institutes and laboratories of basic research with world-class achievements.

The theory of the "triple helix" is also consistent with the idea of creating network structures and industrial clusters that should unite around diversified universities that create innovations and supply specialists for such structures [9, 10]. An example, of course, is Silicon Valley in the USA and its "clones" around the world. Such structures can consolidate the intellectual, financial and material resources of several state research centers, universities and industrial companies on a regional and sectoral basis. A modern university should become not just an educational, but also a research and entrepreneurial organization. This creates interdependence between universities and industrial companies, and the state acts as a venture capitalist.

In Russia, the "triple helix" has a certain specificity, which consists in the fact that the bulk of fundamental 
research is not at universities, as in most countries of the world, but at institutes of the Russian Academy of Sciences. At the same time, universities carry out the bulk of training, including the highest qualifications, in the context of a rather weak scientific base and a modest scale of R\&D funding. Creating an infrastructure to facilitate the development of links between science and business in such a system is not a trivial task, since the formation of infrastructure around universities will be affected by a lack of scientific potential and funding at universities, as well as a lack of young staff in scientific organizations. Although there is a good example of cooperation between Akademgorodok near Novosibirsk with NSTU and the Institute of Problems of Chemical Physics in the Moscow Region with Moscow State University [11].

It is useful here to mark the experience of China, there universities and most industrial companies remain in state ownership (as in Russia). As it was noted above, 7 universities of China are in the first hundred of the QS rating, which is a consequence, first of all, of overcoming disunity of academic and university science. Using the strategy of "catching up development", China has created powerful modern industry on Western technologies, has increased its GDP many times and has positive trade balance with the USA, European Union and Russia, which allows it to invest huge funds not only in economic development, but also in higher education, and unconditionally accepting Western model of universities [12].

\section{Results}

Russian economy is based on a shaky foundation for the country's export of raw materials. The stability of the national currency and surplus or deficit of the state budget depends on energy prices. High energy prices at the beginning of the XXI century allowed the country to accumulate significant cash reserves and raise the standard of living of the population, but were insufficient to reform the economy, ensure long-term sustainable economic growth, reform education and health care. The completion of the recent boom in commodity markets, coupled with the collapse in world oil prices in 2014 and 2019, highlighted the vulnerability of the commodity-oriented economic development and the need to differentiate the economy and develop a high-tech sector.

Given favorable conditions in the commodity markets, Russia could afford to import equipment (including for the commodity industries), vehicles and necessary technologies. In the context of the crisis and economic sanctions, it was necessary to switch to an import substitution strategy. However, it should be understood that, in principle, it is impossible to carry out complete import substitution of complex products (consumer electronics, automobiles, airplanes, etc.) without bringing the entire chain, including engineering education, industry and public administration to the world level of competitiveness.

A weak spot in the preparation of students of engineering specialties is production practice (more precisely, acquisition of skills in real engineering activity). It often uses the form of cooperation of graduating departments with the relevant enterprises (usually the defense industry), used since the "Soviet times" [13]. This collaboration allows students to see their future jobs, but it is far from real engineering. Unfortunately, there are very few competitive high-tech civilian companies in Russia, and they do not seek to invite students. In addition, the internship begins only at the senior courses and consists, at best, in the implementation of auxiliary work, since really engineering work is often not enough for the main staff, which clearly shows labor productivity even in such high-tech industries as aviation and rocket space $[14,15]$.

The relatively low salaries of graduates of technical universities at state enterprises are a consequence of low labor productivity, limited domestic market, and uncompetitive products in foreign markets. It is known that the competitiveness of company products in foreign markets lies through domestic competition. In a competitive market economy, an engineer must not only have a high level of knowledge of mathematics, physics and technology for the production of structures from new materials, but also offer innovative solutions that bring economic benefits to the enterprise he works for $[16,17]$.

\section{Discussion}

The basis of the policy of the leading countries of the world regarding higher education is to maintain the quality of education through priority funding, high requirements for teachers and students and innovative R\&D in universities. International university rating reflects the cross-country competition of states in higher education as part of the overall economic competition between countries and economic unions such as European Union. It is estimated that improvement of scientific knowledge and its application gives from 20 to $40 \%$ growth: process in which the leading role belongs to universities, since the vast majority of fundamental and applied research is concentrated there [18].

The economic crises that have regularly shocked Russia over the past thirty years are the result of a lack of reform of the command economy into a market economy, weakness of market institutions and relatively low quality of higher education. Russia needs to make wider use of the world experience of "catching up" development (China, Republic of Korea and countries of Eastern Europe) in terms of creating high- and medium-tech industrial companies, increasing labor productivity, 
reforming universities and developing production of competitive civilian goods. Government regulation should complement and not replace a market mechanism based on competition and the interaction of supply and demand. Now there is not so much Russian industry that needs to be, but highly qualified specialists capable of creating innovative products and working in a highly competitive world environment.

In terms of the number of students in higher education (over 4000000 people), Russia is at the level of developed countries, but significantly lags behind them in terms of funding. The main source of funding remains state budget and relatively small tuition fees for some students. Obviously, the quality of education directly depends on the level of funding for universities, and this indicator in many countries is the basis for solving the question: "How many and what kind of specialists should be trained at universities in the country?" European Union countries this level is $12000-15000$ dollar per student per year. In the USA and Great Britain, it is higher. Only top universities (MIPT, MEPhI, Moscow State University) are approaching this level [19]. Salaries of professors and associate professors in Russia and developed countries vary significantly. To meet the demand for higher education in Russia, it is advisable to develop for free (or for a small fee) various forms of distance learning, tested during the COVID-19 pandemic.

In order to compete with the world's leading manufacturers of high-tech products, it is necessary to start with competitive technical universities, closely connected with production, in which teachers, students and scientific laboratories would correspond to the world level. Only then it will be possible to create "breakthrough" products and to reduce the technological gap with developed countries. Moreover, the emphasis should be on the production of civilian products, where foreign manufacturers receive main income, which allows for expensive R\&D. Further reform of Russian higher education should follow the path of democratization, rather than bureaucratization, which takes a lot of time from university professors and researchers [20].

The experience of many countries has shown that the reform of higher education should be accompanied by targeted state activities to create a new economic structure, eliminate obsolete industries and carry out institutional reforms. At the same time, large defense companies are no longer the "driver" of the country's economic development and often borrow technological innovations from civilian companies [21]. Fierce competition in the civilian sectors forces companies to create innovations precisely in these sectors of the economy, from where they "flow" into defense companies. If the state had not reimbursed part of the costs to defense enterprises (especially in the field of $R \& D$ ), the latter would have had to significantly reduce the number of production units and the number of employees [22].

\section{Conclusion}

Based on the study, to overcome the gap in the position of Russian engineering universities in international rankings, the author considers it necessary to carry out the following reforms:

1. To strengthen the civic orientation and differentiation of technical universities, traditionally oriented towards defense industry enterprises, by adding faculties and programs that are part of international subject ratings. This will help bridge the gap in such industries as civil aircraft construction, civil use of space, robotics, alternative energy, etc.

2. To expand the scientific and practical base of technical universities at the expense of industry and academic research institutes. Currently, engineering is divided into academic, sectoral and university, while around the world it is concentrated around technical universities.

3. Only strong scientific laboratories at universities can rejuvenate and modernize the teachers of universities, give the opportunity to be $\mathrm{PhD}$ or Doctor and stop the emigration from Russia of young scientists and engineers.

4. Reforming engineering universities should take place simultaneously with a partial conversion of defense industry enterprises and the attraction of private capital to high-tech industries. The internship of students in military-industrial complex industry enterprises does not give students an idea of the competition in which civilian manufacturers around the world participate.

5. It is necessary to free higher education from bureaucratization, to ensure world-wide standards for the ratio of teaching and research work at teaching staff.

\section{REFERENCES}

[1] UNESCO, UNESCO report, 2010, Online available from: http://www.unesco.org/new/en/natural-sciences/science-tec hnology/engineering/engineering-education/unesco-enginee ring-report

[2] L. B. Sobolev, Advanced tendencies of Russian training in engineering, Journal of Physics: Conference Series ICMSIT 2020, 1-6, 2020.

[3] Topuniversities, QS World University Rankings, 2020, Online available from https://www.topuniversities.com/qsworld-university-rankings/methodology

[4] A. V. Shestopalova, Comparative analysis of statistics and methodology of world university rankings, Problem analysis and public administration design, Vol.9, No.45, 84-100, 2016.

[5] Topuniversities, QS World University Rankings by Subject, 
2019, Online available at: https://www.topuniversities.com/ subject-rankings/2019

[6] U.S. News, Overview of Massachusetts Institute of Technology, 2020, Online available at: https://www.usnews .com/best-colleges/massachusetts-institute-of-technology-2 178

[7] E. Caraynnis, D. Tharsten, D. Campbell, The Quintuple Helix innovation model: global warning as a challenge and driver for innovation, Journal of Innovation and Entrepreneurship, No.1, 2, 2012.

[8] N. V. Smorodinskaya, Triple helix as a new matrix of economic systems, Innovation, Vol.4, No.150, 66-78, 2011.

[9] D. Baggerly, Productivity and efficiency remain key challenges for the aerospace industry, 2017, Online available at:

https://www.supplyon.com/en/blog/productivity-efficiencyremain-key-challenges-aerospace-industry/

[10] L. B. Sobolev, Network form of business organization in aviation corporations, Proceedings of Moscow Aviation Institute, Vol.59, 31-37, 2012.

[11] IPCPRAS, Official website of Institute for Problems of Chemical Physics RAS, 2020, Online available at: https://www.icp.ac.ru/ru/

[12] A. N. Gusev, K. R. Kashfullina, K. A. Nasonov, Higher Education Reform in China and Republic of Korea: Using Foreign Experience in System Modernization, Bulletin of International Organizations, Vol.9, No.1, 124-144, 2014.

[13] R. P. Simonyants, Problems of engineering education and their solution with the participation of industry, Science and Education: Scientific Edition, Vol.3, 394-419, 2019.
[14] L. B. Sobolev, Productivity and remuneration in the global aircraft industry, Economic analysis: theory and practice, Vol.18, No.10, 1881-1893, 2019.

[15] A. Kronemer, J. E. Henneberger, Productivity in aircraft manufacturing, Monthly Labor Review, 24-33, 1993.

[16] Analytical Center for the Government of the Russian Federation, Reform of Higher Education: Domestic and Foreign Experience, 2017, Online available at: https://ac.gov.ru/archive/files/publication/a/14650.pdf

[17] Official EU website, National Reforms in Higher Education (in Austria), 2020, Online available at: https://eacea.ec.europa.eu/national-policies/eurydice/conten t/national-reforms-higher-education-1_en

[18] V. Tambovskaya, I. Rozhdestvenskaya, Reform of higher education in Russia: international experience and economic theory, Issues of Economics, Vol.5, 97-108, 2014.

[19] T. V. Panfilova, Reforming higher education in Russia: democratization or bureaucratization? Social sciences and modernity, Vol.4, 65-72, 2010.

[20] The Village, How much does one student cost for universities? 2018, Online available at: https://www.the-vill age.ru/village/city/news-city/314807-student

[21] K. K. Vijayan, O. J. Mork, I. E. Hansen, Eye Tracker as a Tool for Engineering Education, Universal Journal of Educational Research, Vol.6, No.11, 2647-2655, 2018.

[22] F. Sarsar, Ö. A. Çakir, M. J. Bohórquez, \& M. Van Leeuwen, Learners' and Instructors' Views on Technology Supported Engineering Education: Initial Outcomes in a Cross-Cultural Study Sample, Universal Journal of Educational Research, Vol.6, No. 12, 2764-2771, 2018. 